\section{THE ICE AGE IN SWITZERLAND*}

$\mathrm{T}$ one might venture to use the word "romantic" in I reference to the history of any past geological period, it would certainly with most fitness be applied to that time, so recent and yet so remote, which we know as the Ice Age. The story of the old glaciers, like that of the living ones, has a perennial interest. We listen to it over and over again without wearying, much as we used to do with some of the standard tales of childhood. For even though we are now familiar with the evidence which proves that, at no very distant date, the northern parts of Europe and America, including nearly, if not the whole, of our own country, lay buried under a vast sheet of ice, the fact is so strange that every fresh presentation of it comes even yet before us with not a little of the charm of novelty. Hence every description of new facts which tends to elucidate the history of the Ice age in any one locality possesses a more than local interest and importance. More particularly is this the case when the description relates to Switzerland. The Swiss glaciers of to-day have become in a manner the common property and fighting-ground of the geologists of all countries; and all fresh observations which bear on the ancient extension of these glaciers are welcomed as additions to the common fund of geological knowledge.

But there is a peculiar interest attaching to the publieation the title of which is given below. It is not only a most meritorious contribution to geological literature, showing in great detail the history of glacial phenomena in one of the Swiss cantons, but it may be taken by all local scientific societies as a model of what enthusiasm and industry, well directed, may accomplish. Its origin and growth may be briefly stated. In December of 1867 the Natural History Society of Aargau determined that the year $r 869$, being the fiftieth of its existence, should be marked by some fitting celebration. It was suggested that, besides the usual festivities, it would be well if the society would engage in some piece of scientific work, so as to present the result at the anniversary; and it was finally resolved to make an extended and detailed survey of the erratic formations of the canton. General attention had been roused to this subject by the Swiss Naturalists' Society in 1867. That body had issued a circular inviting all authorities and private individuals throughout Switzerland to preserve the erratic blocks which were rapidly disappearing before hammer and gunpowder. MM. Favre and Soret, of Geneva, had likewise pointed out the desirability of having an accurate map made of the distribution of erratics in the country, Accordingly communications were entered into with the federal and cantonal authorities, who cheerfully lent their assistance. A circular was sent out inviting all and sundry to give their aid towards the ascertaining and mapping of the erratic blocks in the canton Aargau. In that document were likewise given directions as to the nature of the observations to be made. Each of the fellow-workers was requested to note in a schedule the erratic blocks (or foundlings, as they are happily termed in German) of his neighbourhood, with an exact record of the locality of each block, its local name, height above the sea,

* Ueber die erratischen Bildungen im Aargau, \&c. Ein Beitrag zur Kenntniss der Eiszeit, von F. Mühlberg. (Aarau: H. R. Sauerländer.) proprietor, the nature of the rock of which it consists, the legends, if any, connected with it, such human marks as might have been carved on it, and any other remarks that might seem important. To conduct the whole inquiry a reporter or secretary was appointed. His duties were to receive and reduce into connection and order the reports of the various volunteer surveyors; and that he might the better perform this task, he was authorised at the public cost to visit the more remarkable locali ties, to mark those blocks which he considered it desirable to preserve in the interests of science, and to preserve two type specimens of all the more important blocks, the one specimen to be deposited in the Aargau Museum, the other to be sent to M. Favre at Geneva. The blocks lying on State property were to be considered thenceforth inviolable, and for the conservation of those resting on other lands the secretary was authorised to treat with the proprietors with a view to the acquisition of the blocks by the State. By thus taking advantage of the general movement the Aargau Society not only aicled in a work of national interest, but gained an opportunity of celebrating in a singularly excellent way its own anniversary.

The result of the undertaking is now before us in the form of an octavo volume of upwards of 200 pages, with a map showing the distribution of erratics and the extension of the old glaciers over the canton. A more admirable piece of work has not been done in glacial geology for some time. The society deserves the warmest thanks, and more especially the reporter, Herr Mühlberg, who first suggested the task, and on whom the main share of the labour has fallen. The course of each of the ancient glaciers is traced by the lines of "foundlings" which it has left in its path. The evidence furnished by the Canton Aargau as to the retreat of the ice is carefully collected. The limits of the second glaciers are mapped out, and abundant details are furnished as to their moraines. It has long been familiar knowledge that the great glacier of the Rhone, after abutting against the Jura mountains, pushed an immense body of ice eastwards over the lowlands of Switzerland as far as the district round Soleure. But we now learn that rocky debris borne along by the huge glacier has been traced even up to the Rhine at the confluence of the Aar. Swelled by the numerous streams of ice which came down from the Bernese Oberland, the united glacier of the Rhine and Rhone must have poured an enormous mass of ice down the Rhine valley, between the Black Forest and the Jura.

The sequence of events in Switzerland since the close of the Tertiary period is thus epitomised by Herr Mühlberg :-

I. Close of the Tertiary period, elevation of the Alps, \&c.

2. Erosion of the valleys in the area of the molasse.

3. Renewed elevation of the Jura, formation of the barriers at Aarburg, Wildegg, \&c., and consequent lakebasins.

4. First and greatest extension of the glaciers even to the highest crests of the Jura and over the whole canton. Northern limit of theice unknown; accumulation of bottom moraines (Grundmoräne, moraines profondes) upon the "Stoss-seite" of the hills.

5. Retreat of the glaciers, with deposit of earthy rubbish, angular blocks, scratched stones, sand and gravel ; filling up of the lakes behind the above-named barriers (save 
the still-existing lakes over which the retreat of the ice, if it took place at all, was rapid); erosion of the river terraces.

6. New advance of the glaciers to a line drawn from Dagmersellen to Baden; overlaying of the older glacial deposits with fresh erratic materials; formation of large moraines; origin of the small cross-valleys in the molasse hills outside of the ice-covered region.

7. Periodic retreat of the glaciers (with perhaps an occasional renewed advance) until the ice had finally retired from the canton; newer deposits of moraines, \&c., and formation of lakes and marshes where the moraines were laid down across valleys.

8. Changes which are still going on.

There is nothing, indeed, which is novel in this synopsis, but it is satisfactory to find that it is borne out by so large an array of evidence as the author has here brought together. On one or two points we could have wished for information. There is no record given of the direction of the striæ on the rocks. No doubt the molasse is not well adapted for the preservation of such markings, though they would remain even on that rock when protected by superficial clayey deposits. We can hardly doubt that if looked for, striated rock surfaces would be found in Aargau as good as those in the adjoining canton of Solothurn. Herr Miihlberg says nothing of any warmer interglacial epoch, as indicated by lignites lying between the deposits of the first and second glacier periods. Is it that no such evidence exists in Aargau, or that the attention of the observers was not specially directed to this subject?

We cordially commend this little volume to the notice of local scientific societies in this country. Such societies often fail of success, either because on the one hand they are too ambitious and seek to emulate the greater societies in such a manner as to ensure certain failure; or, because, though they possess the will and the ability to work, they lack the strength and the enthusiasm which spring out of well-directed and hearty cooperation, Let them take a lesson from the way in which the Aargau Natural History Society has celebrated its fiftieth anniversary.

ARCH. GEIKIE

\section{PRIVITIVE MAN}

Primițive Man. By Louis Figuier. Revised Translation. 8vo: (London: Chapman and Hall, I870.)

A FIGUIER has been singularly fortunate in the 1. mode in which his books have been received by the French public. "Le Monde avant le Deluge" had a large circulation, and even in England the translation revised by $\mathrm{Mr}$. Bristow met with considerable favour. It is almost needless to remark that it reproduces the wild catastrophic doctrines that were given up in England some thirty years ago, with a grace and elegance which lead the dilettante reader to believe that he is learning at the feet of a modern Gamaliel. "H'Homme Primitif" takes up the narrative where it was dropped by the preceding work, and tells the story of the early races of men that have lived in Europe, with that vivacity and idealism which is only to be found in perfection among the people for whom it was written. It is undoubtedly true that M. Figuier's works give a faithful outline of the present state of science in France; but it is none the less true that in England catastrophism is practically extinct, and that many of the inferences of French Archasologists are received by English savants with a considerable amount of reserve. We, therefore, hold that Science is not really advanced by these books being put before the non-scientific English reader. Of the two books the latter is by far the best, but it is disfigured by many and grave mistakes. There can be no doubt that it will become almost as popular in England as in France, although the elegance of style cannot be preserved in plain straightforward English.

"Primitive Man," the English editor tells us, is intended to "fill an open place in the literature of Prehistoric Archæology," although it covers precisely the sarne ground as Sir John Lubbock's "Prehistoric Times," and rivals that work in size. If this means that "the Raffaelesque idealism" of the illustrations is intended to find its way to the hearts of a British public that is given to sensational literature, we think that the editor is right. The frontispiece, representing a family of the Stone age, is admirably adapted to arrest the attention of the mother of a family; and the feasting during the Stone and Bronze ages is fitted to strike gourmands, the pictures of the chase, sportsmen; while the cultivation of gardens during the Bronze epoch is a toiching scene of rural happiness. A man is hoeing the ground, while a woman is sowing seed, and hard by stands Phyllis with a basket on her head, and leading a favourite goat that is reaching forward to eat a tempting vegetable (also of the Bronze age), while Corydon up an apple tree is shaking its riches into Galatea's lap, and behind are the sheep tended by a shepherdess, and kine and long-snouted pigs are looking on from the palings. All this is extremely pretty, and will doubtless attract many readers. We doubt, however, whether an appetite for archæological knowledge created by such stimulants would be satisfied with the sober logic of the English standard works on the subject. In the Ietterpress we have failed to detect any fact of high importance which is not to be found in "Prehistoric Times," or in "The Antiquity of Man." The English edition of "Primitive Man" has been corrected and altered from the French original, and therefore may be treated as a purely English work. In his preface the editor is so anxious to give reasons for translating the book, that he secms conscious that he holds a bad brief. We shall proceed to point out some of the more glaring mistakes.

M. Figuier gives an account of the celebrated controversy about the Moulin-Quignon jaw, in which he states that Dr. Falconer, Dr. Carpenter, Professor Busk, and Mr. Christy "unanimously agreed in recognising the correctness of the conclusions arrived at by the indefatigable geologist of A bloville," viz., that the flint haches and the human jaw were of the same Quaternary age as the extinct mammalia found in the same gravel pit. So far from this being the case, Dr. Falconer stated in the proces-verbaux that " the churacter which the jaw presents, taken in connection with the conditions under which it lay, are not consistent with the said jaw being of any very great antiquity," while Prof. Busk wrote that "the internal condition of the bone is wholly irreconcileable with an antiquity equal to that assigned to the deposits in which it was found." Mr. Evans also afterwards 